\title{
Correction to: Trust issues
}

Judith Simon (ed.): The Routledge handbook of trust and philosophy, New York and London: Routledge, 2020. 433 pp, £190 HB, £35,99 e-book

\section{Mikkel Gerken ${ }^{1}$}

Accepted: 15 June 2021 / Published online: 7 July 2021

(c) Springer Nature B.V. 2021

\section{Correction to: Metascience https://doi.org/10.1007/s11016-021-00659-8}

Due to typesetting mistakes regarding the position of the title and subtitle this Book Review has been updated.

Publisher's Note Springer Nature remains neutral with regard to jurisdictional claims in published maps and institutional affiliations.

The original article can be found online at https://doi.org/10.1007/s11016-021-00659-8.

\section{Mikkel Gerken} mikkel@sdu.dk

1 University of Southern Denmark, Odense, Denmark 